\title{
PENERIMAAN ORANG TUA PADA ANAK BERKEBUTUHAN KHUSUS DI DESA TIMPUK KECAMATAN SEKADAU HILIR KABUPATEN SEKADAU
}

\author{
Iis Marlina, Amrazi Zakso, Dr. Supriadi \\ Program Studi Magister Pendidikan Sosiologi FKIP Untan Pontianak \\ Email: iismarlina1015@gmail.com
}

\begin{abstract}
The goal of the study was to determine parental acceptance of children with special needs by examining the type of parental acceptance, the treatment given to abk by parents, and the factors that influence parental acceptance. A qualitative research paradigm was applied, with a phenomenological approach and data collection procedures such as observation, interview, and documentation. Because of God's supreme sacrifice and will, children with exceptional needs were well welcomed by their families, according to the findings. There are six types of parental acceptance in children with exceptional needs. However, the most important of the four is (1) to calm his spirit and accept with sincerity, 2) to provide aid and recognition, which can be observed when parents are not ashamed or awkward to bring their children, 3) to pay adequate attention, and 4) to have additional patience. There are children who are complimented by their parents for receiving good treatment from their families, such as addressing the needs of children, offering affection in the form of touch, hugs, providing education, or teaching religious science. Children are treated unfairly in the form of mocking, bullying, scolding, lack of support, and being misjudged. Wrong treatment causes subliminal rejection in children with exceptional needs, as others notice parents who are less loving toward their children. The acceptability of children with special needs is inextricably linked to their surroundings. The most important component in determining parental approval is 1) Support from extended relatives 2) Family unity, 3) Religious background, 4) Community Environment, and 5) Family Economic Situation.
\end{abstract}

Keywords: Parental Acceptance, Special Needs Children

\section{PENDAHULUAN}

Setiap orang tua menginginkan dan menunggu kehadiran anak/anak mereka dalam keluarga kecilnya. Selain itu, setiap orang tua juga berharap agar anaknya terlahir sempurna, sehat, dan tanpa kekurangan apapun. Namun ternyata tidak semua harapan orang tua yang ingin memiliki anak yang sempurna dan sehat itu terwujud, karena terdapat pula anak yang memiliki keterbatasan sejak lahir dan tidak tumbuh dalam keadaan normal. Anak seperti ini biasanya dikatakan anak berkebutuhan khusus, atau banyak sekali istilah lain yang dipakai. Anak berkebutuhan khusus (special needs children) adalah anak yang pernah mengalami cacat fisik, mental, sosial dan emosional atau kelainan fisik pada anak, 
begitupula dalam proses tumbuh kembang.

Menurut Mirza (2011, p.38) mengatakan bahwa setiap orang tua akan merasa tidak percaya, marah, berharap tidak salah diagnosa, shock, panik, sedih, bingung, ketika pertama kali mendengar anaknya mengidap autisme. Kebanyakan orang tua merasa sulit menerima kenyataan bahwa anaknya memiliki gangguan autis tersebut. Orang tua cenderung cemas, bingung dan tidak yakin tentang kondisi yang dihadapi anaknya dimasa akan datang. Kebanyakan orang tua juga memikirkan reaksi lingkungan sosial ketika mengetahui bahwa mereka memiliki anak autis.

Senada dengan Jordan (Joko Yuwono, 2012, p.115) terdapat beberapa hal akan dihadapi orang tua yang memiliki anak autis diantaranya adanya ketidak-ahlian orang tua dalam menangani anaknya, harga diri orang tua, ketidakyakinan orang tua terhadap masa depan anak/kecemasan tentang masa depan anak, akibat yang lebih komplek, akibat emosi sosial, dukungan informasi dan dukungan sosial yang kurang.

Data yang diperoleh dari Badan Pusat Statistik (BPS) pada tahun 2017, sebanyak 1,6 juta jiwa terdapat jumlah anak berkebutuhan khusus (ABK) di Indonesia, dengan jenis gangguan anak yang terjadi sangat bervariatif. Pada Indonesia satu sampai lima dari setiap 1.000 kelahiran mengidap kondisi berkebutuhan tersebut. Sedangkan data yang diperoleh dari UPT LDAC tahun 2020 yaitu sebanyak 866 berkebutuhan khusus yang terdapat di Kota Pontianak. Anak berkebutuhan khusus dalam memenuhi kebutuhanya sangatlah bergantung pada orang lain, termasuk orang paling dekat yaitu orang tua.
Bahkan juga respon masyarakat terhadap anak berkebutuhan khusus tersebut agar dapat bersosialisasi dengan lingkungan sekitarnya.

Desa timpuk merupakan satu diantara desa yang berada di kecamatan sekadau hilir. Data juni 2020 dengan jumlah penduduk 5.131 jiwa dengan penduduk laki-laki 2.575 jiwa dan penduduk perempuan 2.556 jiwa. Desa timpuk memiliki 8 dusun yang akan dipecah menjadi beberapa desa, dusun tersebut ialah sempelas, beringin maju, bumi rejo, tigur, tigur jaya, tabai, setor dan setor karya. Desa timpuk memiliki luas daerah yang lebih besar, juga berdasarkan prariset/observasi yang dilakukan pada lokasi menemukan permasalahan sesuai dengan penelitian.

Pada lokasi penelitian memiliki kondisi disabilitas yang berbeda-beda ada juga anak yang masih belum sekolah, putus sekolah, bahkan hanya diam dirumah saja. Kemudian jarak ke daerah kota yang memiliki fasilitas lebih baik juga tidak mudah, sehingga sebagian yang memiliki keterbatasan tidak bersekolah. Data anak berkebutuhan khusus yang akan menjadi objek penelitian yaitu 5 anak berkebutuhan khusus diantaranya SR, SD, HN, DV dan DN. Pemilihan ini didasari karena objek berumur dibawah 18 tahun dan juga ada yang memiliki keterbatasan sejak lahir, membutuhkan uluran tangan masyarakat dan keluarga supaya dapat berkembang dengan baik.

Anak berkebutuhan khusus (ABK) dianggap berbeda dengan anak normal, dianggap anak yang tidak berdaya, atau mengganggu sehingga perlu dikasihani. Oleh karena itu, tidak menutup kemungkinan ada orang tua yang menerima atau hanya pasrah terhadap kondisi tersebut. Terlebih lagi respon atau sikap masyarakat sekitar anak 
mengarah kepada perkembangan yang positif atau negatif untuk anak berkebutuhan khusus. Karena penerimaan anak berkebutuhan khusus sangat penting untuk pertumbuhan dan perkembangan anak.

Tidak sedikit pasangan mengalami konflik karena tidak adanya persamaan persepsi dan saling mendukung. Orang tua merasa sedih, shock, bingung terhadap diagnosis yang diterimanya. Kemudian orang tua juga kesulitan dan terlambat saat mendeteksi perkembangan anak. Adapun penuturan orang tua yaitu orang tua SD tidak tahu awalnya bahwa anaknya memiliki disabilitas. Saat dokter menyarankan anaknya untuk membatasi pergaulan, membuat orang tua SD kesal atau marah, tanpa memberitahukan penyebabnya. Shock, sedih, bingung saat itu dirasakan oleh orang tua SD, karena untuk penyakitnya tidak dapat disembuhkan dengan obat. Akhirnya, semakin SD semakin besar juga orang tua SD jadi mengerti maksud dari perkataan dokter. Adapun kasus lain bernama SR dimana orang tuanya broken home. Sekarang dia berumur 17 tahun, secara fisik anak tersebut terlihat baik. Namun ternyata jika berbicara tidak terdengar karena kecil suaranya dan tidak jelas, takut terhadap orang lain sehingga lebih sering bermain sendiri di halaman rumah, mata yang kurang fokus, juga lebih banyak berbicara sendiri karena kurangnya bergaul atau berbicara dengan orang lain. Saat masih kecil SR sering dibawa bermain oleh ibunya namun setelah mengetahui kondisi SR, orang tua SR sudah jarang melakukannya lagi karena takut mengganggu orang lain. Fenomena inilah yang menarik perhatian peneliti untuk meneliti tentang penerimaan orang tua pada anak berkebutuhan khusus di Desa Timpuk Kecamatan Sekadau Hilir
Kabupaten Sekadau, dengan bertujuan untuk mendeskripsikan, mengetahui dan memperoleh informasi tentang bentukbentuk penerimaan, perlakuan, dan faktor penerimaan orangtua pada anak berkebutuhan khusus di Desa Timpuk Kecamatan Sekadau Hilir dimana keterbatasan atau kekurangan baik dari segi mental, fisik, emosi-sosial dan lainnya.

\section{PENERIMAAN \\ Definisi Penerimaan Orang Tua}

Orang tua merupakan orang terdekat dan utama pada anak, juga memiliki peranan penting dalam perkembangannya. Perlakuan yang diberikan orang tua pada anak tentu memberikan suatu dampak langsung atau tidak langsung baik itu positif atau sebaliknya. Reaksi setiap orang tua tentunya berbeda, dengan reaksi menerima atau menolak. Terlebih lagi di pedesaan dengan pengetahuan tentang anak berkebutuhan khusus masih minim. Oleh karena itu, Penerimaan dan kesiapan mengasuh anak berkebutuhan khusus sangat diperlukan untuk merangsang pertumbuhan dan perkembangan anak. Penerimaan merupakan perbuatan menerima dan perlakuan yang dilakukan oleh seseorang terhadap orang lain, mengakui baik atau buruk suatu individual dan menerimanya tanpa melihat fisik, suku, bangsa dan lainnya. Penerimaan orang tua yang memiliki anak berkebutuhan khusus memberikan pengaruh terhadap anak, seperti berinteraksi, lebih percaya diri, tidak merasa diabaikan dan tidak ada paksaan, keadilan/kesetaraan tanpa dibedakan. 


\section{Bentuk-Bentuk Penerimaan Orang tua}

Nini Subini (2013, p.64-p.81), bentuk-bentuk penerimaan orang tua ada enam diantaranya tenang jiwanya dan menerima dengan ikhlas, memberi pendampingan dan pengakuan, memberi perhatian yang cukup, memiliki kesabaran ekstra, mengembangkan kelebihan, mengusahakan terapi. Adapun kriteria yang digunakan dalam menentukan penerimaan orang tua dengan melihat bentuk penerimaan yaitu hanya 1 atau 2 bentuk dinyatakan cukup, 3 atau 4 bentuk penerimaan dikatakan sudah baik dan 5 atau 6 bentuk sudah sangat baik.

\section{Perlakuan Orangtua}

Kata Perlakuan menurut kamus besar bahasa Indonesia berarti suatu perbuatan yang dikenakan pada sesuatu atau seseorang (Sugiyono dan Maryani, 2008, p.862). Dikategorikan bisa perlakuan yang baik atau salah, disebabkan karena adanya interaksi antara pelaku dan korban perlakuan. Adapun pembatasan dalam melihat perlakuan orang tua diterima anak berupa secara fisik, perlakuan secara psikologis atau emosional, perlakuan secara verbal/non, perlakuan yang tidak membedakan antar anak lainnya. Perlakuan orang sekitar, baik itu sikap menerima maupun menolak kehadiran mereka sangat berpengaruh pada diri anak berkebutuhan khusus. Perlakuan baik seperti penerimaan yang baik di lingkungan keluarga maupun di lingkungan sosial membuat anak lebih merasa aman, kepercayaan diri meningkat dan lebih mudah berinteraksi dengan orang lain. Akan tetapi, lain halnya dengan anak berkebutuhan khusus yang mendapat perlakuan salah.
Mereka cenderung lebih tertutup dan sulit bergaul dengan orang lain.

\section{Faktor Penerimaan Orang Tua}

Adapun faktor-faktor penyebab penerimaan orang tua menurut Ratih Putri Pratiwi \& Afin Murtiningsih (2013, p.19-p.104) yaitu: adanya dukungan dari keluarga, bergabung dalam berorganisasi, sikap para ahli terhadap diagnosis anak, ekonomi keluarga, latar belakang agama), latar belakang agama, usia masing-masing orang tua, keutuhan keluarga, sikap masyarakat umum.

\section{Anak Berkebutuhan Khusus}

Anak berkebutuhan khusus (special needs children) merupakan anak yang memiliki ciri yang berbeda dengan anak pada umumnya, mengalami hambatan dalam pertumbuhan dan perkembangan (Atmaja, 2019, p.1).

\section{METODE PENELITIAN}

Peneliti menggunakan metode kualitatif dikarenakan penulis bermaksud untuk memahami fenomena tentang apa yang dialami oleh subjek penelitian misalnya perilaku, persepsi, motivasi, tindakan dan lain-lain secara holistik dan dengan cara deskripsi dalam bentuk kata-kata dan bahasa, pada suatu konteks khusus yang alamiah dan dengan memanfaatkan berbagai metode alamiah. Menurut Creswell (2015, p.8) ada lima pendekatan dalam penelitian kualitatif yaitu studi naratif, studi fenomenologi, studi ground theory, studi etnografi dan studi kasus. Sesuai hal tersebut pendekatan yang peneliti gunakan yaitu fenomenologi merupakan rancangan penelitian yang memiliki ciri khas dimana peneliti mendeskripsikan pengalaman kehidupan manusia tentang suatu fenomena tertentu karena disabilitas sebagai realitas dalam 
dimensi perbedaan atau keunikan manusia, bukan sebagai kerusakan atau kecacatan. Adapun cara memperoleh data menggunakan observasi dan wawancara langsung dengan narasumber kemudian dianalisis. Analisis data yang dilakukan diantaranya berbagai aktivitas seperti reduksi data, penyajian data dan verifikasi data. Kemudian pemeriksaan keabsahan data dengan triangulasi, perpanjangan penelitian dan dokumentasi.

Subjek penelitian yaitu 5 keluarga yang memiliki anak berkebutuhan khusus. Adapun orang tua yang menjadi kriteria dalam penelitian ini: (1) ayah atau ibu yang memiliki anak berkebutuhan khusus berusia 1-18 tahun, (2) berdomisili dalam satu desa, (3) subjek bersedia berpartisipasi dalam penelitian ini. Kelima keluarga itu adalah pasangan orang tua yang anaknya bernama DN dan $\mathrm{HN}$, seorang Ibu dari DV (suami keluar kota), Ibu yang anaknya bernama SD (single parent, cerai mati), dan Ibu dari anak bernama SR (single parent, cerai hidup).

\section{HASIL PENELITIAN DAN PEMBAHASAN}

Hasil

Penelitian ini untuk mendeskripsikan dan memperoleh gambaran mengenai penerimaan orang tua pada anak berkebutuhan khusus dengan hal yang dibahas yaitu bentuk penerimaan orang tua, perlakuan yang diperoleh dan faktor penerimaan orang tua. Subjek 1 merupakan pasangan orang tua dengan anak bernama $\mathrm{HN}$ yang mengalami ketunaan ganda pada dirinya, subjek 2 pasangan orang tua dengan anak bernama DN mengalami ketunaan fisik (tunadaksa), subjek 3 seorang ibu dari pasangan suami istri yang anaknya bernama DV juga sama mengalami ketunaan fisik, subjek 4 ibu single parent dengan anak yang bernama SD memiliki disabilitas intelektual dan subjek 4 ibu single parent dengan anak bernama SR disabilitas mental. Penuturan kelima keluarga tidak tahu bahwa anaknya memiliki keterbelakangan pada awalnya, meskipun setiap orang tua berbeda-beda dalam mengetahui kondisi anak namun perasaan awal yang dirasakan subjek tetap sama diantaranya rasa shock, stress, sedih, bingung, marah, tidak percaya. Terlebih hal yang dirasakan oleh pasangan orang tua DN, dimana disabilitasnya disebabkan karena DN sakit kejang dan panas namun terlambat untuk mengatasinya. Rasa sedih dan penyesalan pada orang tua DN begitu besar pada keadaan anaknya tersebut. Yang lebih parahnya adalah subjek 5 mengalami depresi, juga dampak karena adanya anak berkebutuhan khusus pada pernikahan yang berujung perceraian, banyak konflik yang dirasakan oleh orang tua karena ketidaksamaan persepsi. Kemudian pengetahuan yang terbatas mengenai anak mereka menyebabkan kebingungan.

Proses penerimaan setiap subjek pada anak berkebutuhan khusus berbeda-beda. Menurut Gunarsa (2003, p.23), kemampuan penyesuaian diri dari ibu memengaruhi psikologis dari ibu sendiri dan juga perkembangan anak. Ibu yang mampu menyesuaikan diri dengan baik memiliki kondisi psikologis yang sehat dan berdampak positif bagi perkembangan anaknya. Sebaliknya, ibu yang tidak mampu menyesuaikan diri dengan baik memiliki kondisi psikologis yang tidak sehat dan berdampak negatif bagi perkembangan anaknya. Jika orang tua telah benar-benar menyadari dan memahami kondisi anaknya dan menerima apapun yang terjadi, maka muncul sikap penerimaan terhadap 
kekurangan serta keterbatasan yang ada pada anak mereka. Orang tua DV mulai membuat perencanaan agar kondisi DV lebih baik dengan operasi pada bibirnya, orang tua HN, SD menyadari bahwa anaknya perlu sekolah khusus dan terapi. Namun biaya dan kondisi dari kedua orang tua yang kurang memadai sehingga memperhambat penangananya, orang tua DN hanya melatih untuk berjalan dan menggunakan tangan lainnya dalam beraktivitas dan keterbatasan biaya dan juga pengetahuan minim orang tua SR menyebabkan tidak adanya terapi yang di ikuti.

Berdasarkan hasil wawancara ke lima subjek orang tua anak berkebutuhan khusus, empat diantaranya sudah mampu menerima anak dengan sangat baik. Namun salah satu subjek, masih kurang maksimal dan merasa tidak puas sehingga belum dapat mendukung perkembangan pada anaknya. Adapun bentuk-bentuk penerimaan orang tua yaitu orang tua mengatakan bahwa anak yang tidak sempurna adalah titipan dari Tuhan, hanya Tuhanlah yang sempurna. Pasrah dengan keadaan yang telah diberikan oleh Allah, karena tidak ada yang bisa diperbuat jika ia sudah berkehendak. Kemudian orang tua mendampingi anak untuk belajar dan mengakui keterbatasan yang dimiliki anaknya, memberikan perhatian yang cukup pada anak, orang tua mencoba memahami maksud yang hendak disampaikan anaknya dengan cara berusaha bertanya dengan pelan-pelan, namun tidak semua orang tua menerima perilaku anak mereka,

Dari hasil penelitian ditemukan bahwa anak berkebutuhan khusus mendapat perlakuan yang berbeda berdasarkan penerimaan yang dirasakan oleh orang tua, juga pengalaman/ pengetahuan yang menurut keluarga itu adalah sesuatu yang benar. Hasil wawancara tidak adanya perbedaan perlakuan antar anak di keluarga, anak diberikan pelukan dan usapan kepala, memperhatikan kebutuhan anak, tidak memaksa kehendak anak, sering memuji anak. Adapun perlakuan salah pengobatan anak belum maksimal, dan sekolahnya. Subjek ke 5 ditemukan baju yang digunakan anak kurang bersih, anak cenderung diam jika bersama ibunya, anak banyak dibiarkan bermain sendiri, dianggap bodoh, kurang mampu, jarang dibawa pergi kemana-mana. Alasan yang mendasari hal tersebut karena orang tua single parent sebagai kepala keluarga, kondisi ekonomi. Penerimaan yang diperoleh anak berkebutuhan khusus tidak terlepas dari faktor keadaan. Faktor yang dominan dalam mempengaruhi penerimaan orangtua 1) keutuhan keluarga, 2) latar belakang agama, 3) lingkungan masyarakat, 4) ekonomi keluarga.

\section{Pembahasan}

Pada umumnya, reaksi pertama kali yang muncul pada orang tua ketika anaknya memiliki permasalahan pada kondisi fisik maupun lainnya adalah tidak percaya, adanya goncangan batin dalam dirinya, dan tidak mempercayai kenyataan yang menimpanya. Respon lain yang ditunjukkan adalah penolakan dengan berbagai alasan seperti merasa tidak percaya, sedih, bingung, stress, pasrah dengan keadaan yang dialami, marah pada diri sendiri, orang lain dan Tuhan, serta tidak dapat menerima kenyataan. Hal ini wajar dan normal, karena pada dasarnya setiap orangtua menginginkan yang terbaik buat anaknya.

Dalam proses penerimaan terhadap anak bekebutuhan khusus, subjek 1, 2, 3 dan 4 sudah dapat menerima kondisi 
anak apa adanya dan berusaha untuk menolong anak mereka. Sedangkan subjek 5 orangtua dari SR yang telah disebutkan sebelumnya yakni perempuan single parent belum sepenuhnya menerima kondisi anaknya. Hal ini dikarenakan adanya perasaan stres yang masih ada sampai saat ini, sebab ia harus mengasuh anaknya sendiri tanpa pendampingan seorang suami. Meskipun orang tua SD juga single parent, namun saat anaknya lahir hingga berumur 4 tahun, suami masih mendukung satu sama lainnya sebelum meninggal kemudian SD merupakan anak bungsu dari pasangan tersebut dengan 5 saudara, oleh karena itu orang tua SD memiliki pengalaman dalam memperlakukan anak.

Bentuk-bentuk penerimaan orang tua yaitu: (1) Orang tua DV, SD, HN, DN saling berkomunikasi dengan keadaan anaknya, anak sebagai amanah. Meskipun ibu US sempat malu selama beberapa bulan karena kondisi anaknya, ibu DN yang selalu menyesali atas keterlambatan dalam penangan. Namun subjek orang tua SR tidak mendapatkan dukungan oleh pasangan menyebabkan kesalahan dalam perlakuan yang diberikan secara tidak disadari. Orang tua DV, SD, HN, DN mengintropeksi diri atas keadaan yang menimpa anaknya, begitu juga orang tua SR yang tidak seharusnya memarahi anak atas kekurangan yang dimiliki sehingga perlu memaklumi. (2) Semua subjek merawat anaknya dengan segala kekurangan, meskipun pada awalnya ada perasaan iri terhadap orang yang memiliki anak normal. (3) Semua subjek merasa cemas terhadap masa depan anak mereka. Namun orang tua DN yakin bahwa ada yang menerima DN apa adanya. Orangtua DV fokus terhadap perkembangan anak dan yakin bahwa anaknya harus bisa hidup seperti anak normal lainnya. Orang tua HN kurang yakin terhadap masa depan $\mathrm{HN}$, namun mereka tetap fokus membimbing dan menjaga $H N$ supaya lebih mandiri kedepannya. Begitu juga orang tua SR, meskipun acuh namun SR diajarkan mandi sendiri dan mengurus dirinya agar tetap aman. Begitu juga dengan SD tetap diperlakukan seperti anak seumurannya, bersosialisasi, mencoba membaca meskipun perkembangannya kurang. (4) Orang tua memberikan perhatian terhadap anak mereka dengan memberikan nasehat apabila diejek, memberikan elusan/pelukan/pujian terhadap anaknya.

Seperti halnya data yang didapatkan oleh peneliti, keterkejutan mengetahui anak mengalami kelainan bisa terwujud dalam bentuk perasaan sedih, bingung serta kecemasan yang mendalam. Reaksi orang tua dijelaskan sebagai suatu tahapan yang dilalui orang tua ketika mereka mulai bisa menerima ketimbang terus bersedih atas keadaan anak yang tidak diharapkan. Tahapan-tahapan reaksi tersebut sebagaimana yang dijabarkan oleh Drotar dkk antara lain: terguncang jiwanya, menolak, sedih, cemas, takut, marah dan akhirnya menerima/menyesuaikan diri. Reaksi tersebut bisa saja berbeda-beda pada orang tua yang lain (Smith, 2015: 339).

Perlakuan kelima keluarga (orang tua anak berkebutuhan khusus) mempengaruhi perilaku anak dalam semua tahap pertumbuhannya. Seperti dikatakan Mead mengenai rangsangan dan respon, perlakuan keluarga dalam hal ini merupakan rangsangan (impuls) bagi anak dan anak memberikan tanggapan (respon) berdasarkan perlakuan yang diterima. Nuansa positif dalam keluarga membangun energi dan kepercayaan diri anak untuk 
mengembangkan potensinya dan tidak berfokus pada hambatan yang dimilikinya. Hal tersebut juga bisa membantu anak untuk menemukan kondisi terbaiknya. Jadi idealnya perkembangan anak menjadi optimal jika dibesarkan dalam keluarga harmonis dan saling menghargai kondisi setiap anggotanya. Selain itu, orang tua harusnya bisa menerima bahwa anaknya memiliki kelainan. Meskipun butuh waktu dan proses cukup lama untuk bisa menerima kenyataan tersebut. Namun, semakin orang tua menolak kehadiran mereka, maka semakin sulit dan berat beban yang dirasakan dalam memberikan penanganan terhadap anak. Peristiwa di atas, senada dengan apa yang di ungkapkan oleh teori interaksionisme simbolik (Simbolic Interaktionism Theory) mengenai sikap isyarat (gesture) dimana suatu gerakan dilakukan oleh pihak pertama yang bertindak sebagai rangsangan khusus yang menimbulkan tanggapan dari orang kedua. Dalam mengomunikasikan perasaan tidak senang kepada orang lain bisa saja dengan menggunakan isyarat fisik seperti memasang wajah cemberut atau merajuk atau diam. Hal ini terjadi pada SR, dia akan terdiam tidak banyak bicara saat ibunya dirumah yang menandakan bahwa SR tidak ingin mengganggu ibunya dengan melihat perbuatannya atau takut akan kemarahannya. Tingkah laku ketika sendirian dan bersama ibunya begitu berbeda. SR jika sendirian mengekspresikan banyak hal baik tertawa, berbicara sendiri seakan sedang bermain. Meskipun sang adik menyayangi dia namun adik laki-laki ini sering dibawa ibunya untuk berdagang atau bermain.

Memiliki anak berkebutuhan khusus dan diakui sebagai tantangan yang cukup berat, selain merawat maupun mengasuh membutuhkan tenaga, perhatian, kesabaran yang ekstra karena tidak mudah. Ketika ibu dan bapak mendapatkan karunia seorang anak yang berkebutuhan khusus, tentunya dihadapi dengan situasi yang jauh berbeda. Perlu dukungan yang banyak diberikan, diskusi yang sering dilakukan, kerjasama yang harus dijalani, menunjukan rasa tulus ikhlas terhadap kondisi anak. Seperti halnya menurut Hurlock, tiga faktor yang mempengaruhi penerimaan orang tua diantaranya yaitu dukungan dari keluarga besar, faktor ekonomi, latar belakang agama. Selain itu keutuhan keluarga juga mempengaruhi penerimaan anak berkebutuhan khusus, keluarga yang harmonis satu sama lain, memahami, merasakan membuat rasa percaya diri masing-masing pada anak akan tumbuh dan menerimanya.

Masyarakat juga memiliki peranan penting dalam membantu orang tua untuk menerima anaknya, apalagi jika orang tua tidak memiliki pengetahuan yang cukup pada kondisi anak, masyarakat dapat memberikan informasi dan membantu agar perkembangan anak lebih baik. Kecenderungan masyarakat merasa kasihan, sehingga timbul rasa iba akhirnya dapat memperlakukan anak berkebutuhan khusus dengan baik pula. Orang tua pun merasa bahwa masyarakat tidak mendiskriminasikan anaknya.

\section{SIMPULAN DAN SARA Simpulan}

Bentuk penerimaan terhadap 4 subjek orang tua (HN, SD, DN dan DV) sudah dapat menerima sepenuhnya, hal ini terlihat dari sikap adanya perasaan bersyukur pada Allah SWT sehingga menimbulkan kasih sayang yang besar, sabar dan ikhlas, memiliki pengetahuan yang benar dan cukup tentang kondisi 
disabilitas anak sehingga memahami apa yang tidak bisa dilakukan anak, memahami kebiasaan dan keadaan anak. Sementara yang lain bisa dikategorikan juga baik, masih dalam tahap penerimaan dimana perhatian yang diberikan anak masih kurang maksimal. Bentuk-bentuk penerimaan orang tua pada anak berkebutuhan yang paling dominan sebanyak 4 yaitu (1) tenang jiwanya dan menerima dengan ikhlas, 2) memberi pendampingan dan pengakuan, hal ini terlihat ketika orang tua sudah tidak malu ataupun canggung untuk membawa anaknya, 3) memberikan perhatian yang cukup, 4) kesabaran yang ekstra. Jika dilihat dari perlakuan orang tua pada anak berkebutuhan khusus memiliki keberagaman namun anak diperlakukan dengan baik dan ada pula perlakuan salah yang diterimanya. Disamping itu didapat pula hasil bahwa faktor yang dominan dalam mempengaruhi penerimaan atau penolakan orangtua terhadap anak berkebutuhan khusus diantaranya 1) adanya dukungan keluarga yang begitu penting dari keluarga sekitar, 2) keutuhan keluarga, pasangan yang saling menguatkan dan bekerjasama akan cepat menerima keadaan anak berkebutuhan

\section{DAFTAR RUJUKAN}

Atmaja, J.R. (2019). Pendidikan dan bimbingan (Anak Berkebutuhan Khusus). Bandung: PT Remaja Rosdakarya Offset

Astutik, S. (2014). Penerimaan orang tua terhadap anak berkebutuhan khusus. Undergraduate Thesis, Uin Sunan Ampel Surabaya. khusus, 3) latar belakang agama, mengikuti kegiatan keagamaan dan keimanan akan lebih meningkatkan rasa syukur dengan hadirnya anak berkebutuhan khusus, 4) lingkungan masyarakat yang menerima dengan baik kondisi anak, akan mengurai rasa ketidakpercayaan diri dan meningkatkan perkembangan anak, 5) ekonomi keluarga, jika stabil maka tidak memberikan dampak penolakan yang berlebihan.

\section{Saran}

Meskipun menerima keadaan bukan hal mudah, namun jika dijalankan dengan baik maka mendapatkan sesuatu yang lebih baik dengan memahami kondisi anak. Anak adalah anugerah, perlakuan yang diberikan pasti berdampak pada perkembangan anak kedepannya. Oleh karena itu, peranan orang tua pada anak begitu penting khususnya untuk orang tua yang memiliki anak berkebutuhan khusus. Begitu juga dengan keluarga besar berikan dukungan, motivasi dan perhatian pada orang tua dengan anak berkebutuhan khusus, supaya subjek memiliki dukungan sosial.

Creswell, J.W. (2015). Penelitian qualitatif dan desain riset. Yogyakarta: Pustaka Pelajar.

Elizabeth B.H. (2016). Perkembangan anak. Jakarta: Penerbit Erlangga

Faradila, N. (2016). Penerimaan diri pada orang tua yang memiliki anak berkebutuhan khusus. EJournal Psikologi, Volume 4, Nomor 4, 2016: 386-396 
Fitria. (2010). Pengasuhan dimensi kehangatan keluarga. EJornal IDEA Nursing, Volume 1, Nomor 1, ISSN: 2087-2879

Goffman, E. (1963). STIGMA (Notes on The Management Spoiled Identity). London: Penguins Book

Gordon. (2020). Menjadi orangtua efektif. Jakarta: PT Gramedia Pustaka Utama

Hastuti. (2018). Perlakuan anak berkebutuhan khusus dalam perspektif sosiologi (Studi Kasus Di Sekolah Inklusi Smp Negeri 1 Alla Kabupaten Enrekang). Sekolah Pascasarjana Universitas Hasanuddin: Makassar

Smith, J.D. (2015). Sekolah untuk semua, teori dan implementasi inklusi. Bandung: Nuansa Cendikia

Maryani, Y., dan Sugiyono. (2008). Kamus Bahasa Indonesia. Jakarta: Pusat Bahasa.

Mirza M. (2011). Anak autis: Mendidik anak autis dan gangguan mental lain menuju anak cerdas dan sehat. Jogjakarta: Katahati.

Moleong, L.J. (2017). Metode penelitian kualitatif. cetakan Ke-XXXV. Bandung: PT Remaja Rosdakarya
Pancawati, R. (2013). Penerimaan diri dan dukungan orangtua terhadap anak autis. EJournal Psikologi. Volume 1 Nomor 1, Halaman 3847. Samarinda: Fakultas Ilmu Sosial dan Ilmu Politik Universitas Mulawarman.

Pratiwi, R.P., \& Afin M. (2013). Kiat sukses mengasuh anak berkebutuhan khusus. Yogyakarta: AR-Ruzz Media.

Ritzer, G., Goodman, D.J. (2011). Teori sosiologi. Bantul: Kreasi Wacana

Ritzer, G. (2010). Sosiologi ilmu pengetahuan berparadigma ganda. Rajawali Pers, Jakarta.

Rohner, dkk. (2012). Introduction to parental acceptance-rejection theory, methods, evidence, and implications. Introduction to PARTheory. Revised November 16, 2012. Yogyakarta: Graha Ilmu.

Singgih, G. (2003). Psikologi untuk keluarga. Jakarta: BPK Gunung Mulia.

Subini, N. (2013). Panduan mendidik anak dengan kecerdasan di bawah rata-rata. Yogyakarta: Javalitera

Sugiyono. (2017). Metode penelitian \& pengembangan (Research and development/R\&D. Yogyakarta: Alfabeta 